\title{
Prognostic impact of clinicopathologic parameters in stage II/III breast cancer treated with neoadjuvant docetaxel and doxorubicin chemotherapy: paradoxical features of the triple negative breast
}

\section{cancer}

\author{
Bhumsuk Keam¹, Seock-Ah Im*1,6, Hee-Jun Kim¹, Do-Youn Oh'1,6, \\ Jee Hyun Kim¹,6, Se-Hoon Lee ${ }^{1,6}$, Eui Kyu Chie ${ }^{2}$, Wonshik Han³, Dong- \\ Wan Kim ${ }^{1,6}$, Woo Kyung Moon ${ }^{4}$, Tae-You Kim ${ }^{1,6}$, In Ae Park ${ }^{5}$, Dong- \\ Young Noh ${ }^{3}$, Dae Seog Heo ${ }^{1,6}$, Sung Whan $\mathrm{Ha}^{2}$ and Yung-Jue Bang1,6
}

\footnotetext{
Address: ${ }^{1}$ Department of Internal Medicine, Seoul National University College of Medicine, Seoul, Korea, ${ }^{2}$ Department of Radiation Oncology, Seoul National University College of Medicine, Seoul, Korea, ${ }^{3}$ Department of Surgery, Seoul National University College of Medicine, Seoul, Korea, ${ }^{4}$ Department of Radiology, Seoul National University College of Medicine, Seoul, Korea, ${ }^{5}$ Department of Pathology, Seoul National University College of Medicine, Seoul, Korea and ${ }^{6}$ Cancer Research Institute, Seoul National University College of Medicine, Seoul, Korea

Email: Bhumsuk Keam - bhumsuk@medimail.co.kr; Seock-Ah Im* - moisa@snu.ac.kr; Hee-Jun Kim - dino11@medimail.co.kr; DoYoun Oh - ohdoyoun@snu.ac.kr; Jee Hyun Kim - jhkimmd@snu.ac.kr; Se-Hoon Lee - shlee119@snu.ac.kr; Eui Kyu Chie - ekchie93@snu.ac.kr; Wonshik Han - hanw@snu.ac.kr; Dong-Wan Kim - dwkimmd@chol.com; Woo Kyung Moon - moonwk@radcom.snu.ac.kr; Tae-

You Kim - kimty@snu.ac.kr; In Ae Park - iapark@plaza.snu.ac.kr; Dong-Young Noh - dynoh@plaza.snu.ac.kr;

Dae Seog Heo - heo1013@plaza.snu.ac.kr; Sung Whan Ha - swha@snu.ac.kr; Yung-Jue Bang - bangyj@plaza.snu.ac.kr

* Corresponding author
}

Published: I November 2007

BMC Cancer 2007, 7:203 doi:10.1/86/147/-2407-7-203
Received: 23 May 2007

Accepted: I November 2007

This article is available from: http://www.biomedcentral.com/I47I-2407/7/203

(C) 2007 Keam et al; licensee BioMed Central Ltd.

This is an Open Access article distributed under the terms of the Creative Commons Attribution License (http://creativecommons.org/licenses/by/2.0), which permits unrestricted use, distribution, and reproduction in any medium, provided the original work is properly cited.

\begin{abstract}
Background: Prognostic factors in locally advanced breast cancer treated with neoadjuvant chemotherapy differ from those of early breast cancer. The purpose of this study was to identify the clinical significance of potential predictive and prognostic factors in breast cancer patients treated by neoadjuvant chemotherapy.

Methods: A total of 145 stage II and III breast cancer patients received neoadjuvant docetaxel/doxorubicin chemotherapy were enrolled in this study. We examined the clinical and biological factors (ER, PR, p53, c-erbB2, bcl-2, and $\mathrm{Ki}-67)$ by immunohistochemistry. We analyzed clinical outcome and their correlation with clinicopathologic parameters.

Results: Among the clinicopathologic parameters investigated, none of the marker was correlated with response rate (RR) except triple negative phenotype. Patients with triple negative phenotype showed higher RR $(83.0 \%$ in triple negative vs. $62.2 \%$ in non-triple negative, $p=0.012)$ and pathologic complete RR (17.0\% in triple negative vs. $3.1 \%$ in non-triple negative, $p=0.005)$. However, relapse free survival (RFS) and overall survival (OS) were significantly shorter in triple negative breast cancer patients ( $p<0.00 \mathrm{I}, p=0.02 \mathrm{I}$, respectively). Low histologic grade, positive hormone receptors, positive bcl-2 and low level of $\mathrm{Ki}-67$ were associated with prolonged RFS. In addition, positive ER and positive bcl-2 were associated with prolonged OS. In our homogeneous patient population, initial clinical stage reflects RFS and OS more precisely than pathologic stage. In multivariate analysis, initial clinical stage was the only significant independent prognostic factor to impact on OS (hazard ratio 3.597, $p=0.044$ ).
\end{abstract}


Conclusion: Several molecular markers provided useful predictive and prognostic information in stage II and III breast cancer patients treated with neoadjuvant docetaxel/doxorubicin chemotherapy. Triple negative phenotype was associated with shorter survival, even though it was associated with a higher response rate to neoadjuvant chemotherapy.

\section{Background}

Neoadjuvant chemotherapy has become a standard therapy for patients with locally advanced breast cancer $[1,2]$. Major roles of neoadjuvant chemotherapy are 1) conversion of inoperable or inflammatory breast cancer to operable status 2) increasing the rate of breast conserving surgery, and 3) individual in vivo chemosensitivity test of the tumor [2-4]. However, a potential disadvantage of neoadjuvant chemotherapy is the loss of prognostic value provided by tumor size and nodal status at surgery and before adjuvant chemotherapy $[3,4]$.

A number of studies have investigated prognostic factors in the neoadjuvant setting. At present, pathologic complete response ( $\mathrm{pCR}$ ) is a useful independent prognostic factor and the patients who achieved pCR showed better survival compared with those with residual tumor [5-8]. However a small percentage of patients achieved pCR, and a significant portion of patients with pCR had recurrent disease [9]. Molecular markers such as estrogen receptor (ER), progesterone receptor (PR), p53, Ki-67 and c-erbB2 considered predictive or prognostic factors in neoadjuvant setting $[7,10-14]$. However, these markers are often contradictory and not conclusive because of heterogeneous patient populations, small sample sizes, and different chemotherapeutic regimens. Due to alterations in molecular mechanism during neoadjuvant chemotherapy, and also uncertainty regarding the prognostic value of clinicopatholgic parameters, physicians felt difficulties to accurately define risk profiles and identify optimal post operation treatment including chemotherapy and radiation therapy.

We ourselves have conducted neoadjuvant docetaxel/doxorubicin combination chemotherapy in stage II and III breast cancer patients. The purpose of this study was to identify the clinical significance of potential predictive and prognostic factors in the neoadjuvant setting.

\section{Methods}

\section{Patients and treatment}

From March 2002 to March 2006, patients were enrolled in this study. Eligibility criteria included: 1) pathologically confirmed breast cancer by core needle biopsy, 2) clinical stage II or III, 3) objective measurable lesion, 4) ECOG performance 0-2, 5) previously untreated, 6) adequate bone marrow, hepatic, cardiac, and renal functions. Initial evaluation included clinical examination, mammography, breast ultrasonography, computed tomogra- phy of chest, bone scan, and breast magnetic resonance imaging (MRI). Initial tumor size was measured by MRI. Initial nodal staging was evaluated by physical examination and by computed tomography. After three cycles of neoadjuvant chemotherapy, the patients were re-evaluated for response.

The chemotherapeutic regimen comprised docetaxel (75 $\mathrm{mg} / \mathrm{m}^{2}$ or $60 \mathrm{mg} / \mathrm{m}^{2}$ ) and doxorubicin $\left(60 \mathrm{mg} / \mathrm{m}^{2}\right.$ or 50 $\mathrm{mg} / \mathrm{m}^{2}$ ) by intravenous infusion every three weeks for three cycles, with granulocyte colony stimulating factor as primary prophylaxis. After completion of neoadjuvant treatment, the patients underwent primary surgery and received three more cycles of docetaxel and doxorubicin as adjuvant chemotherapy, followed by radiation or hormonal therapy if indicated [15]. If the patients had been found to have progressive disease, they underwent primary surgery and received adjuvant chemotherapy using different regimens. This regimen was known to be effective and well tolerated as neoadjuvant chemotherapy for stage II or III breast cancer [16].

Radiologic response was evaluated using breast MRI for primary breast cancer measurement and chest CT for lymph node measurement by RECIST criteria [17] as follows; complete response was defined as the complete disappearance of all assessable lesions; partial response as a $>30 \%$ reduction in the sum of the longest diameters of all measurable lesions; stable disease as a $<30 \%$ reduction or $\mathrm{a}<20 \%$ increase in the sum of the longest diameters of all measurable lesions; and progressive disease was defined as $>20 \%$ increase in the area(s) of original measurable lesion or the appearance of a new lesion.

We examined the conventional clinicopathologic factors including the six different biological factors (ER, PR, p53, c-erbB2, bcl-2, and Ki-67) by immunohistochemistry and evaluated their association with clinical outcomes. The study protocol was reviewed and approved by the institutional review board at the Seoul National University Hospital. Recommendations of the Declaration of Helsinki for biomedical research involving human subjects were also followed.

\section{Pathologic Examination and Immunohistochemistry}

The pretreatment formalin-fixed, paraffin-embedded tissue blocks were used for immunohistochemistry. The pathological tumor stage assessed according to the criteria established by the 6th edition of AJCC cancer staging 
manual [18], the grade of the tumor according to the Scarff-Bloom-Richardson classification modified by Elston and Ellis [19]. The pathologic complete response $(\mathrm{pCR}$ ) was defined as complete disappearance of invasive carcinoma in both breast and axillary lymph nodes after three cycles of chemotherapy. Residual ductal carcinoma in-situ was included in the PCR category.

ER, PR, c-erbB2, p53, bcl-2, and Ki-67 expressions were evaluated by the avidin-biotin complex immunohistochemical technique [20]. Tissue sections (4- $\mu$ m thickness) from paraffin-embedded tissue blocks were cut, deparaffinized in xylene, rehydrated with graded ethanol, and immersed in Tris-buffered saline. After an antigenretrieval process, primary antibodies were used as previously described [21]. The companies that supplied the primary antibodies and the dilution factors used were; ER (Dako Corporation, Carpinteria, CA, USA; 1:50), PR (Dako Corporation; 1:50), c-erbB2 (Novocastra Laboratories Ltd., New Castle-Upon-Tyne, U.K.; 1:200), p53 (Dako Corporation; 1:1200), bcl-2 (Dako Corporation; 1:50), and Ki-67 (Dako Corporation; 1:800). All primary antibodies were mouse monoclonal antibodies. Biotinylated anti-mouse antibody was used as secondary antibody and streptavidin horseradish peroxidase (Zymed laboratories, San Francisco, CA, USA) methods were used.

A cut-off value of $10 \%$ or more positively stained nuclei in ten high-power fields was used to define ER and PR positivity. C-erbB2 scores of 0,1 and 2 were considered negative, and a score of 3 was considered positive [22]. In the current study, we did not have FISH information available on the majority of c-erbB2 positive patients. Ki-67 with $\leq$ $5 \%$ and p53 with $<25 \%$ were considered as low expression. Triple negative subtype was defined as ER negative, PR negative, and c-erbB2 negative, regardless of the expression of EGFR or basal cytokeratins.

\section{Statistical analysis}

The significance of the difference in the response rate among different groups was calculated using the Chisquared test and Fisher's exact test, where appropriate. Multivariate analyses were carried out using the Cox proportional hazard regression models. Relapse free survival (RFS) was determined as the interval between the initiation of neoadjuvant chemotherapy and the date when disease relapse or progression was first documented or the date of death from any cause. Overall survival (OS) was measured from the date of neoadjuvant chemotherapy initiation to the date of death. Survival comparisons between different groups were made using the log-rank tests. All values were two sided and statistical significance was defined as $p<0.05$. SPSS version 12.0 software (SPSS, Inc., Chicago, IL, USA) was used for all statistical analyses.

\section{Results}

\section{Patient Characteristics and efficacy}

A total of 145 patients with a median age of 45 (range 25$69)$ were evaluated in this study. The clinical characteristics of the patients are summarized in Table 1. Most of the patients $(84.1 \%)$ were clinical stage III at the time of initial diagnosis and eighteen patients (12.4\%) had inflammatory breast cancers. The median tumor size was $5 \mathrm{~cm}$ which is relatively large for Asian woman who have small breast. The breast conserving surgery rate was 35.9\%. The overall radiologic response rate (RR) was $68.9 \%$ including 7 complete response $(4.8 \%)$ and 93 partial response (64.1\%) (Table 2). All 7 radiologic complete responder showed pCR and four patients who showed radiologic residual lesion were turned out to pCR. Consequently, eleven patients (7.6\%) achieved a pCR (Table 2).

Of 145 patients, 138 patients including patients with pCR received three more cycles of docetaxel and doxorubicin as planned adjuvant chemotherapy. Three patients who showed progressive disease and 4 patients who were unacceptable to docetaxel received different adjuvant chemotherapy using FAC (5-fluorouracil, doxorubicin, cyclophosphamide), AC (doxorubicin, cyclophosphamide) or CMF (cyclophosphamide, methotrexate, 5-fluorouracil) after curative surgery.

Median follow-up duration was 18.6 months. Estimated one and three year relapse free survival rates were $88.7 \%$ and $56.5 \%$, respectively. Estimated one and three year overall survival rates were $97.5 \%$ and $71.6 \%$ respectively.

\section{Correlation between clinicopathological variables and response rate}

Potential traditional predictive factors (age, performance, stage, nuclear grade, histologic grade, ER, PR, p53, cerbB2, bcl-2 and Ki-67) were analyzed. Table 3 compares radiologic $\mathrm{RR}$ and predictive factors. pCR was correlated with radiologic $\mathrm{RR}(p=0.018)$. $\mathrm{PCR}$ and radiologic $\mathrm{RR}$ according to ER/PR/c-erbB2 are summarized in Table 4. Patients with triple negative breast cancer showed higher RR ( $83.0 \%$ in triple negative $v s .62 .2 \%$ in non-triple negative, $p=0.012)$.

\section{Correlation between clinicopathological variables and survival}

The results of univariate analyses for RFS and OS were shown in Table 5. Responding to neoadjuvant chemotherapy did not affect RFS or OS. Among the parameters investigated, low histologic grade, positive ER, positive PR, positive bcl-2 and low level of Ki-67 were associated with prolonged RFS in univariate analysis. In addition, positive ER and positive bcl-2 were associated with prolonged overall survival (OS) in univariate analysis. In terms of stage, initial clinical stage reflects RFS and OS more pre- 
Table I: Clinical characteristics of I45 patients

\begin{tabular}{|c|c|}
\hline Characteristics & No. of $\mathrm{Pt}(\%)$ \\
\hline Median age (range) & 45 (range $25-69$ ) \\
\hline Age $<50$ & $102(70.3)$ \\
\hline Age $\geq 50$ & $43(29.7)$ \\
\hline \multicolumn{2}{|l|}{ Performance status } \\
\hline ECOG 0-I & $139(95.9)$ \\
\hline ECOG 2 & $6(4.1)$ \\
\hline \multicolumn{2}{|l|}{ Pathologic characteristics } \\
\hline Invasive ductal carcinoma & $137(94.5)$ \\
\hline Others & $8(5.5)$ \\
\hline \multicolumn{2}{|l|}{ Initial clinical stage } \\
\hline$\| \mathrm{A}$ & $2(1.4)$ \\
\hline IIB & $21(14.5)$ \\
\hline IIIA & $70(48.3)$ \\
\hline IIIB & $34(23.4)$ \\
\hline IIIC & $18(12.4)$ \\
\hline Median tumor size & $5.0 \mathrm{~cm}($ range $1.2-12.0 \mathrm{~cm})$ \\
\hline \multicolumn{2}{|l|}{ Inflammatory breast cancer } \\
\hline Yes & $18(12.4)$ \\
\hline No & $127(87.6)$ \\
\hline \multicolumn{2}{|l|}{ Type of surgery } \\
\hline Breast conserving & $52(35.9)$ \\
\hline Mastectomy & $93(64.1)$ \\
\hline \multicolumn{2}{|l|}{ Adjuvant hormonal therapy } \\
\hline Yes & $63(43.4)$ \\
\hline No & $82(56.6)$ \\
\hline \multicolumn{2}{|l|}{ Radiation therapy } \\
\hline Yes & $128(88.3)$ \\
\hline No & $17(11.7)$ \\
\hline
\end{tabular}

ECOG, Eastern Cooperative Oncology Group.

cisely than pathologic stage. Kaplan-Meier plots (Figure 1) show the survival curve according to clinical and pathologic stage.

We also performed multivariate analysis (Table 6). Cox proportional hazard regression analysis for OS included statistically significant variables (initial clinical stage, ER, bcl-2, and triple negative). In multivariate analysis, initial clinical stage was the only significant independent prognostic factor to impact on OS (hazard ratio 3.597, $p=$ 0.044).

Table 2: Radiologic and pathologic response after docetaxel plus doxorubicin neoadjuvant chemotherapy

\begin{tabular}{lc}
\hline Response & No. of Pts (\%) \\
\hline Radiologic response & \\
$\quad$ Complete response & $7(4.8)$ \\
Partial response & $93(64.1)$ \\
Stable disease & $42(29.0)$ \\
Progressive disease & $3(2.1)$ \\
Pathologic complete response & \\
Yes & $11(7.6)$ \\
No & $134(92.4)$ \\
\hline
\end{tabular}

\section{Clinical significance of triple negative breast cancer}

Forty seven patients (32.4\%) of the 145 were triple negative breast cancer. Clinicopathologic variables according to triple negative are summarized in Table 7 . Triple negative breast cancer patients showed statistically higher nuclear grade, and lower bcl-2 positive rate than non-triple negative breast cancer patients. A trend for high levels of Ki-67 was also observed in triple negative, although it did not reach statistical significance ( $p=0.053)$. The $\mathrm{pCR}$ rate and clinical $\mathrm{RR}$ in triple negative were significantly higher ( $p=0.005, p=0.012$, respectively). However, RFS and OS were significantly short in triple negative breast cancer patients $(p<0.001, p=0.021$, respectively). RFS and OS survival curves for triple negative and non-triple negative are shown in Figure 2. Because c-erbB2 positivity by immunohistochemistry was unclear, we conducted a second analysis considering $2+$ as c-erbB2 positive. Using this definition of triple negative, the results were similar.

\section{Discussion}

The clinical course of breast cancer patients treated with neoadjuvant chemotherapy remains difficult to predict, because histologically homogeneous breast cancers vary in response to therapy and have divergent outcomes [23]. 
Table 3: Correlation between clinicopathological variables and radiologic response rate

\begin{tabular}{|c|c|c|c|c|}
\hline Variables & & No. of Pts & Responders (RR \%) & p-value* \\
\hline Age & $\begin{array}{l}<50 \\
\geq 50\end{array}$ & $\begin{array}{l}102 \\
43\end{array}$ & $\begin{array}{l}69(67.6) \\
31(72.1)\end{array}$ & 0.597 \\
\hline Performance & $\begin{array}{c}\text { ECOG 0-I } \\
\text { ECOG } 2\end{array}$ & $\begin{array}{c}139 \\
6\end{array}$ & $\begin{array}{c}95(68.3) \\
5(83.3)\end{array}$ & 0.666 \\
\hline Initial clinical stage & $\begin{array}{c}\|A,\| B, I I A \\
\| I I B, I I C C\end{array}$ & $\begin{array}{l}93 \\
52\end{array}$ & $\begin{array}{l}64(68.8) \\
36(69.2)\end{array}$ & 0.959 \\
\hline \multirow{2}{*}{$\mathrm{pCR}$} & No & 134 & $89(66.4)$ & 0.018 \\
\hline & Yes & II & II (100.0) & \\
\hline \multirow[t]{3}{*}{ Nuclear grade } & I, II & 41 & $22(53.7)$ & 0.069 \\
\hline & III & 87 & $61(70.1)$ & \\
\hline & Unknown & 17 & - & \\
\hline \multirow[t]{3}{*}{ Histologic grade } & I, II & 39 & $24(61.5)$ & $0.74 I$ \\
\hline & III & 82 & $53(64.6)$ & \\
\hline & Unknown & 24 & - & \\
\hline \multirow[t]{2}{*}{ ER } & Positive & 64 & $41(64.1)$ & 0.257 \\
\hline & Negative & 81 & $59(72.8)$ & \\
\hline \multirow[t]{2}{*}{ PR } & Positive & 44 & $28(63.6)$ & 0.360 \\
\hline & Negative & 101 & $72(71.3)$ & \\
\hline \multirow[t]{3}{*}{ bcl-2 } & Positive & 63 & 45 (7I.4) & 0.749 \\
\hline & Negative & 74 & $51(68.9)$ & \\
\hline & Unknown & 8 & - & \\
\hline \multirow[t]{3}{*}{$\mathrm{Ki}-67$} & Low expression\# & 56 & $34(60.7)$ & 0.066 \\
\hline & High expression & 85 & $64(75.3)$ & \\
\hline & Unknown & 4 & - & \\
\hline \multirow[t]{3}{*}{ p53 } & Low expression\# & 67 & $43(64.2)$ & 0.219 \\
\hline & High expression & 76 & $56(73.7)$ & \\
\hline & Unknown & 2 & 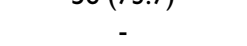 & \\
\hline \multirow[t]{2}{*}{ c-erbB2 } & $0 /+/++$ & 107 & $76(7 \mid .0)$ & 0.368 \\
\hline & +++ & 38 & $24(63.2)$ & \\
\hline \multirow[t]{2}{*}{ Triple negative } & No & 98 & $61(62.2)$ & 0.012 \\
\hline & Yes & 47 & $39(83.0)$ & \\
\hline
\end{tabular}

$R R$, response rate; $P C R$, pathologic complete response; ER, estrogen receptor; PR, progesterone receptor. *based on Pearson's $\chi^{2}$ test (using Fisher's exact test if $\mathrm{N} \leq 5$ ).

$\# \mathrm{Ki}-67$ with $\leq 5 \%$ and $\mathrm{p} 53$ with $<25 \%$ were considered as low expression.

As a result, many researchers have tried to identify prognostic factors in order to give optimal individualized therapy in locally advanced breast cancer, as well as in early breast cancer. Currently, pCR is the most powerful prognostic factor for prolonged survival in neoadjuvant chemotherapy $[3,5,6,24]$. However, a significant proportion of patients with pCR have recurrent diseases [9]. Moreover, the prognostic factors for patients receiving neoadjuvant chemotherapy differ from those for patients who receive adjuvant or palliative chemotherapy, because pathologic parameters including tumor size and nodal status are changed by neoadjuvant chemotherapy [3]. Hence we tried to determine the additional predictive and prognostic markers for early relapse other than PCR in neoadjuvant setting.

Table 4: Pathologic complete response and radiologic response rate according to ER/PR/c-erbB2

\begin{tabular}{|c|c|c|c|c|c|c|}
\hline & & No. of Pts & $\mathrm{pCR}(\mathrm{N}=1 \mathrm{I})$ & p-value & Radiologic Response (RR \%) & p-value \\
\hline Variables & & & No. of Pts (\%) & & No. of Pts (\%) & \\
\hline \multirow[t]{2}{*}{ ER } & Positive & 64 & I (I.6) & 0.023 & $4 I(64.1)$ & 0.257 \\
\hline & Negative & 81 & $10(12.3)$ & & $59(72.8)$ & \\
\hline \multirow[t]{2}{*}{$\mathrm{PR}$} & Positive & 44 & I (2.3) & 0.173 & $28(63.6)$ & 0.360 \\
\hline & Negative & 101 & $10(9.9)$ & & $72(7 \mid .3)$ & \\
\hline \multirow[t]{2}{*}{ c-erbB2 } & $0 /+/++$ & 107 & $9(8.4)$ & 0.728 & $76(71.0)$ & 0.368 \\
\hline & +++ & 38 & $2(5.3)$ & & $24(63.2)$ & \\
\hline
\end{tabular}



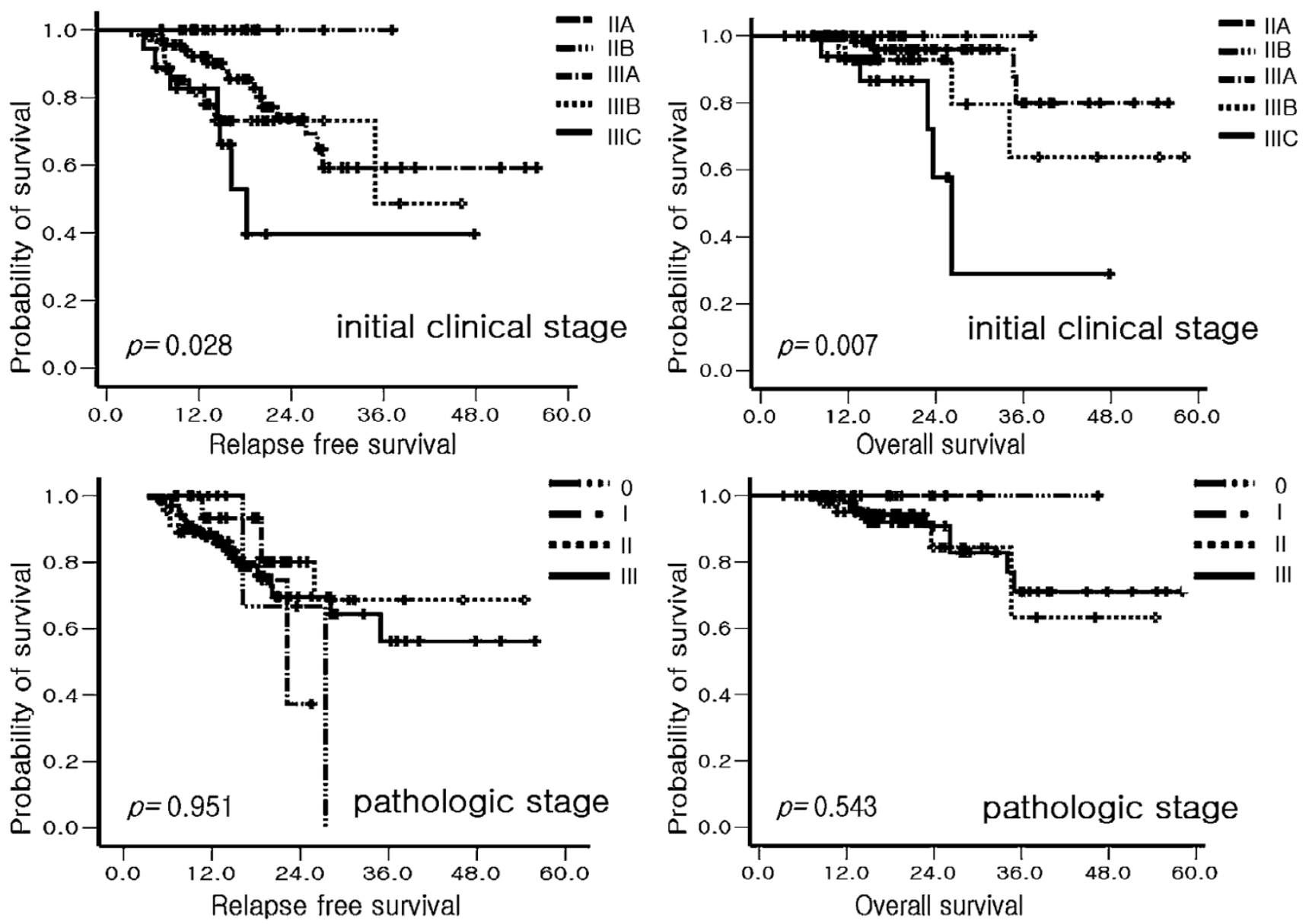

Figure I

Kaplan-Meier analyses of survival according to clinical and pathologic stages.

In the present study, we found that a triple negative phenotype was a predictive marker for response in neoadjuvant docetaxel and doxorubicin chemotherapy. In addition, initial clinical stage, hormone receptor, histologic grade, bcl-2 and Ki-67 were all associated with RFS. In other published studies using non-anthracycline based chemoendocrine agents [11], it was reported that positive ER, absence of c-erbB2 and decrease in Ki-67 were associated with a good clinical response. Overexpression of p53 was also reported to be associated with a lower response rate to anthracycline based neoadjuvant chemotherapy $[13,14,25]$ and to be an independent factor for poor survival $[14,25]$. In our results, overexpression of p53 failed to show clinical significance in neoadjuvant setting. However, p53 mutation which was associated with response to neoadjuvant chemotherapy [13] was not in agreement with p53 overexpression measured by quantitative immunohistochemistry. Additional mutational study of p53 is needed to clarify correlation between p53 and clinical outcomes. The predictive or prognostic value of bcl-2, apoptosis regulatory protein, remains controversial in neoadjuvant setting. In one study, higher bcl-2 expression was predictive for pCR [26], while other studies did not find any correlation between bcl-2 expression and clinical response $[25,27]$. Traditional prognostic makers such as nodal stage [28] and c-erbB2 [10,11] showed no prognostic value in our result. Relatively short follow up period of 18.6 months might partially explain this. As yet, these biologic markers are inconclusive, owing to heterogeneous chemotherapeutic regimens and the small sample size of extant studies. More studies should be carried out, to identify more precisely the prognostic markers in the neoadjuvant setting.

In our results, pCR which is considered to be the most powerful prognostic factor did not show significant prognostic value. Possible explanations for the weakened prognostic power of $\mathrm{pCR}$ are the relatively lower rate of pCR (7.6\%), the short course of neoadjuvant chemotherapy, and the short duration of follow up (18.6 months). 
Table 5: Correlation between clinicopathological variables and survival-univariate analysis

\begin{tabular}{|c|c|c|c|c|c|c|}
\hline \multirow[b]{2}{*}{ Variables } & & \multirow[b]{2}{*}{ No. of $\mathrm{Pt}$} & \multicolumn{2}{|l|}{ RFS } & \multicolumn{2}{|l|}{ OS } \\
\hline & & & $\mathrm{HR}^{*}(95 \% \mathrm{Cl})$ & $p$-value & $\mathrm{HR}^{*}(95 \% \mathrm{Cl})$ & $p$-value \\
\hline \multirow[t]{2}{*}{ Age } & $<50$ & 102 & I & 0.317 & 1 & 0.283 \\
\hline & $\geq 50$ & 43 & $1.476(0.688-3.166)$ & & $1.831(0.606-5.533)$ & \\
\hline \multirow[t]{2}{*}{ Performance } & ECOG 0-I & 139 & I & 0.686 & I & 0.888 \\
\hline & ECOG 2 & 6 & $1.349(0.316-5.756)$ & & $1.160(0.148-9.073)$ & \\
\hline \multirow[t]{2}{*}{ Initial clinical stage } & IIA, IIB, IIIA & 93 & $\mathrm{I}$ & 0.017 & I & 0.010 \\
\hline & IIIB, IIIC & 52 & $2.370(1.116-4.815)$ & & $4.764(1.462-15.525)$ & \\
\hline \multirow[t]{2}{*}{$\mathrm{pCR}$} & No & 134 & $\mathrm{I}$ & 0.817 & NA\# & NA\# \\
\hline & Yes & $\mathrm{II}$ & I.I $86(0.28 \mid-5.005)$ & & & \\
\hline \multirow[t]{2}{*}{ Pathologic stage } & $P C R \sim I I A$ & 113 & I & 0.288 & I & 0.086 \\
\hline & IIIB, IIIC & 32 & $1.525(0.700-3.319)$ & & $2.608(0.874-7.786)$ & \\
\hline \multirow[t]{2}{*}{ Pathologic N stage } & No & 42 & 1 & 0.636 & I & 0.566 \\
\hline & $\mathrm{NI}-3$ & 103 & $0.828(0.378-1.8 \mid 2)$ & & I.558 (0.342-7.099) & \\
\hline \multirow[t]{2}{*}{ Radiologic response } & Responder & 100 & I & 0.515 & 1 & 0.683 \\
\hline & Non-responder & 45 & $0.776(0.36 \mid-1.665)$ & & $1.258(0.4 \mid 9-3.775)$ & \\
\hline \multirow[t]{2}{*}{ Nuclear grade } & I, II & 41 & I & 0.151 & 1 & 0.141 \\
\hline & III & 87 & $1.894(0.792-4.532)$ & & $2.689(0.722-10.023)$ & \\
\hline \multirow[t]{2}{*}{ Histologic grade } & I, II & 39 & I & 0.020 & I & 0.132 \\
\hline & III & 82 & $4.159(1.248-13.865)$ & & $4.820(0.62 I-32.387)$ & \\
\hline \multirow[t]{2}{*}{ ER } & Positive & 64 & I & 0.001 & 1 & 0.028 \\
\hline & Negative & 81 & $5.410(2.073-14.119)$ & & 9.921 (I.289-76.349) & \\
\hline \multirow[t]{2}{*}{$P R$} & Positive & 44 & 1 & 0.005 & 1 & 0.166 \\
\hline & Negative & 101 & $7.778(1.85 \mathrm{I}-32.673)$ & & $4.278(0.547-33.476)$ & \\
\hline \multirow[t]{2}{*}{$\mathrm{bcl}-2$} & Positive & 63 & I & 0.034 & 1 & 0.046 \\
\hline & Negative & 74 & $2.351(1.068-5.175)$ & & $4.705(1.030-21.490)$ & \\
\hline \multirow[t]{2}{*}{$\mathrm{Ki}-67$} & Low expression & 56 & I & 0.038 & I & 0.082 \\
\hline & High expression & 85 & $2.357(1.050-5.287)$ & & $3.263(0.86 I-12.363)$ & \\
\hline \multirow[t]{2}{*}{ p53 } & Low expression & 67 & I & 0.869 & I & 0.670 \\
\hline & High expression & 76 & $1.063(0.515-2.193)$ & & I.28I (0.4I0-3.998) & \\
\hline \multirow[t]{2}{*}{ c-erbB2 } & $0 /+1++$ & 107 & I & 0.242 & 1 & 0.678 \\
\hline & +++ & 38 & $1.555(0.742-3.255)$ & & $1.273(0.408-3.973)$ & \\
\hline \multirow[t]{2}{*}{ Triple negative } & No & 98 & I & 0.002 & 1 & 0.029 \\
\hline & Yes & 47 & $3.148(1.539-6.441)$ & & $3.430(1.133-10.378)$ & \\
\hline
\end{tabular}

RFS, relapse free survival; OS, overall survival; $\mathrm{HR}$, hazard ratio; $\mathrm{Cl}$, confidence interval.

* Hazard ratio was calculated by Cox's proportional hazard model. If the hazard ratio is greater than I, the hazard ratio can be thought of as the average increased risk of relapse or dying at any point in time compared with the reference group (described upper line).

\#NA: Not available due to all censored in PCR.

We conducted only three cycles of neoadjuvant chemotherapy, while other neoadjuvant regimens have been based on four to six cycles, and have shown higher PCR rates $(8-26 \%)$ than our own study $[24,29,30]$.

Optimal treatment after neoadjuvant chemotherapy remains still uncertain [31]. Unlike early breast cancer, it is not yet clear whether adjuvant therapy should be conducted according to initial clinical stage or post operative pathologic stage. In our homogeneous patient population, initial clinical stage was an independent prognostic factor for survival, while pathologic stage failed to reflect ultimate survival. This result was obtained by using accurate staging work up modalities, including breast MRI and chest computed tomography. In contrast, Carey et al [32] analyzed 135 patients with median follow up of 5 years and reported that pathologic stage after neoadjuvant chemotherapy was useful for predicting survival. Chollet et al [33] also reported prognostic value of residual tumor size and nodal status after neoadjuvant chemotherapy with median follow up of 9.3 year. However, despite short duration of follow up, our results showed statistical superiority of initial clinical stage in predicting survival. This result might give us useful information when determining post operative adjuvant therapy.

Triple negative breast cancer has been reported as being associated with a poor clinical outcome in early breast cancer $[34,35]$. In locally advanced breast cancer, there are limited data about response to chemotherapy and survival. In the present study, we found that triple negative breast cancer responded to neoadjuvant chemotherapy 
Table 6: Multivariate Cox regression analyses for the factors associated with overall survival

\begin{tabular}{cccc}
\hline & & OS & \\
\cline { 2 - 4 } Variables & HR & $95 \%$ Cl & -value \\
\hline Initial clinical stage & 3.597 & $1.037-12.480$ & 0.044 \\
ER & 3.329 & $0.296-37.454$ & 0.330 \\
bcl-2 & 3.027 & $0.557-16.437$ & 0.200 \\
Triple negative & 1.847 & $0.492-6.935$ & 0.364 \\
\hline
\end{tabular}

initially but then relapsed rapidly. Generally, tumor responsiveness to chemotherapy is believed to be associated with a longer survival. However, in triple negative phenotype, tumor responsiveness did not affect prolonged survival. In contrast, non-triple negative breast cancer did not show a marked response but progressed rather slowly. This paradoxical feature is consistent with other studies conducted in basal-like breast cancer, which was identified using gene expression profiling [36,37]. In the present study, we did not conduct gene expression profiling and hierachial cluster analysis. However, it is known that $80-90 \%$ of triple negative breast cancers by immunohistochemistry are basal-like subtypes by gene expression profiling [35] and have a similar clinical behavior, in addition [38,39]. It is notable that we were able to obtain useful predictive and prognostic information by simple immunohistochemistry without high cost.

It is not yet certain whether the poor prognosis of triple negative breast cancer is due to its aggressive feature or because of lack of targeted therapy, including adjuvant hormonal therapy and c-erbB2 targeted agents. We hypothesized that triple negative breast cancer itself seems to reflect more aggressive tumor biology and growth rate potential with high expression of Ki-67. Our data suggest that patients with triple negative breast cancer should be candidates for clinical trials to determine additional agents including antiangiogenic agents.

\section{Conclusion}

Several molecular markers play a role as predictive and prognostic factors in stage II and III breast cancer patients receiving neoadjuvant chemotherapy. We also confirmed the usefulness of initial clinical stage, as a predictor of survival. We found that triple negative phenotype was associated with shorter survival, even though it was associated with a higher response rate to neoadjuvant chemotherapy. These results might assist in identifying and understanding the importance of clinically useful markers in the neoadjuvant setting, and help to optimize treatments.
(A)

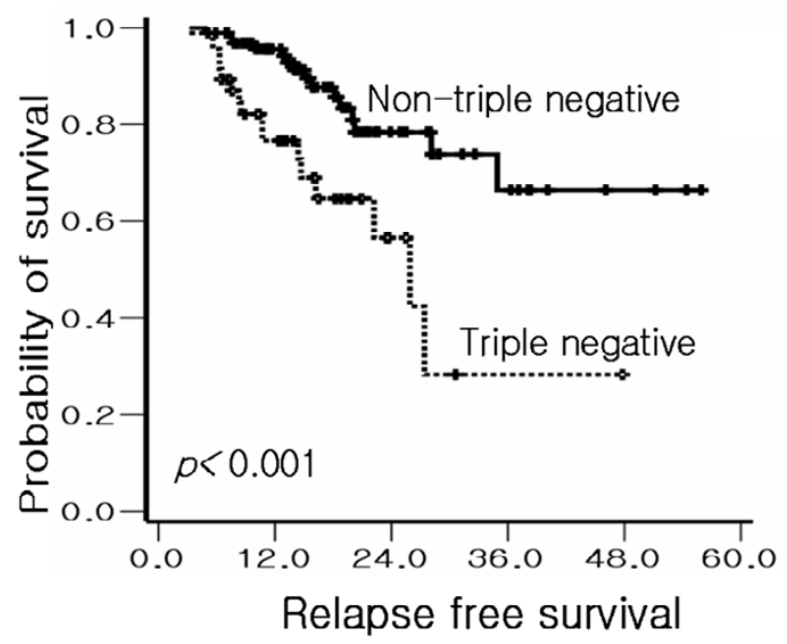

(B)

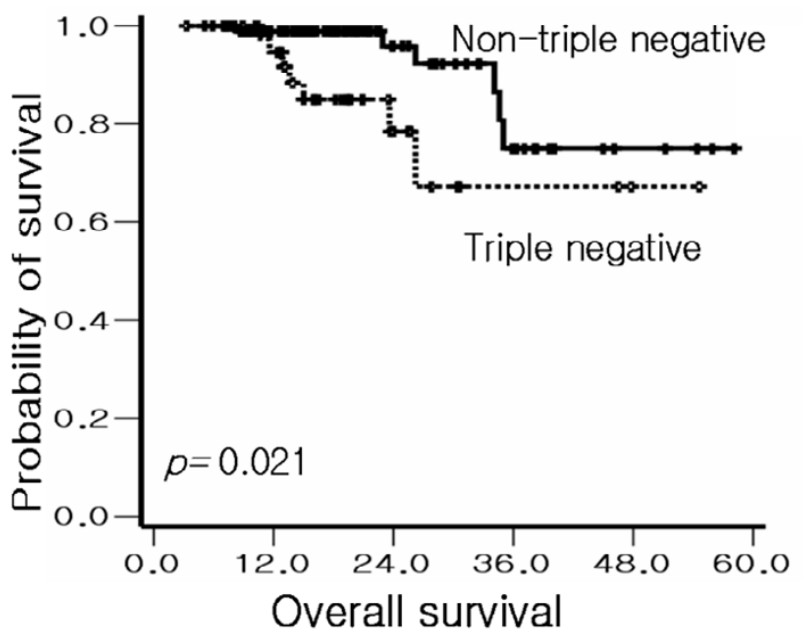

\section{Figure 2}

Kaplan-Meier analyses of $(A)$ relapse free and $(B)$ overall survival according to triple negative and non-triple negative breast cancer. 
Table 7: Clinicopathologic characteristics according to triple negative and non-triple negative breast cancer

\begin{tabular}{|c|c|c|c|c|c|}
\hline \multirow[b]{2}{*}{ Variables } & & \multirow[t]{2}{*}{ No. of Pts } & \multirow{2}{*}{$\begin{array}{c}\text { Triple negative }(\mathrm{N}=47) \\
\text { No. of Pts }(\%)\end{array}$} & \multirow{2}{*}{$\begin{array}{c}\text { Non-triple negative }(\mathrm{N}=98) \\
\text { No. of Pts (\%) }\end{array}$} & \multirow[t]{2}{*}{$p$-value* } \\
\hline & & & & & \\
\hline \multirow[t]{2}{*}{ Age } & $<50$ & 102 & $33(70.2)$ & $69(70.4)$ & 0.981 \\
\hline & $\geq 50$ & 43 & $14(29.8)$ & $29(29.6)$ & \\
\hline \multirow[t]{2}{*}{ Performance } & ECOG 0-I & 139 & $45(95.7)$ & 94 (95.9) & 0.961 \\
\hline & ECOG 2 & 6 & $2(4.3)$ & $4(4.1)$ & \\
\hline \multirow{2}{*}{ Initial clinical stage } & IIA, IIB, IIIA & 93 & $27(57.4)$ & $66(67.3)$ & 0.245 \\
\hline & IIIB, IIIC & 52 & $20(42.6)$ & $32(32.7)$ & \\
\hline \multirow[t]{2}{*}{ Inflammatory breast cancer } & Yes & 18 & $4(8.5)$ & $14(14.3)$ & 0.425 \\
\hline & No & 127 & $43(91.5)$ & $84(85.7)$ & \\
\hline \multirow[t]{2}{*}{ Radiologic response } & Responder & 100 & $39(83.0)$ & $61(62.2)$ & 0.012 \\
\hline & Non-responder & 45 & $8(17.0)$ & $37(37.8)$ & \\
\hline \multirow[t]{2}{*}{$\mathrm{PCR}$} & No & 134 & $39(83.0)$ & 95 (96.9) & 0.005 \\
\hline & Yes & II & $8(17.0)$ & $3(3.1)$ & \\
\hline \multirow[t]{2}{*}{ Adjuvant hormonal therapy } & Yes & 63 & $0(0.0)$ & $63(64.3)$ & $<0.001$ \\
\hline & No & 82 & $47(100.0)$ & $35(35.7)$ & \\
\hline \multirow[t]{2}{*}{ Radiation therapy } & Yes & 128 & $41(87.2)$ & 87 (88.8) & 0.787 \\
\hline & No & 17 & $6(12.8)$ & $I \mid(I I .2)$ & \\
\hline \multirow[t]{2}{*}{ Nuclear grade } & I, II & 41 & $3(8.1)$ & $38(4 \mid .8)$ & $<0.001$ \\
\hline & III & 87 & 34 (91.9) & $53(58.2)$ & \\
\hline \multirow[t]{2}{*}{ Histologic grade } & I, II & 39 & $7(20.0)$ & $32(37.2)$ & 0.066 \\
\hline & III & 82 & $28(80.0)$ & $54(62.8)$ & \\
\hline \multirow[t]{2}{*}{ bcl-2 } & Positive & 63 & $14(31.8)$ & $49(52.7)$ & 0.022 \\
\hline & Negative & 74 & $30(68.2)$ & $44(47.3)$ & \\
\hline \multirow[t]{2}{*}{$\mathrm{Ki}-67$} & Low expression & 56 & $13(28.3)$ & $43(45.3)$ & 0.053 \\
\hline & High expression & 85 & 33 (7I.7) & $52(54.7)$ & \\
\hline \multirow[t]{2}{*}{ p53 } & Low expression & 67 & $22(46.8)$ & 45 (46.9) & 0.994 \\
\hline & High expression & 76 & $25(53.2)$ & $51(53.1)$ & \\
\hline
\end{tabular}

*based on Pearson's $\chi^{2}$ test (using Fisher's exact test if $\mathrm{N} \leq 5$ )

\section{Competing interests}

The author(s) declare that they have no competing interests.

\section{Authors' contributions}

$\mathrm{BK}$ collected the data, performed the statistical analysis and drafted the manuscript. SAI designed the concept of this study, performed the statistical analysis with interpretation and approved the final manuscript. HJK collected the data. DYO, JHK, SHL, DWK, TYK, DSH and YJB performed the chemotherapy for patients and revised the manuscript. EKC and SWH performed radiation therapy for patients and participated in treatment coordination. WH and DYN performed operation and treatment coordination. WKM reviewed the breast images and measured the tumor size. IAP carried out the immunoassays and pathologic examinations. All authors read and approved the final manuscript.

\section{Acknowledgements}

This study was supported by a Korean Research Foundation Grant funded by the Korean Government (MOEHRD, Basic Research Promotion Fund) (KRF-2006-53 I-E00034), a grant from the Seoul National University Hospital Research Fund (05-800-20050I48) and a grant from the Korean Health 2I R \&D Project, Ministry of Health \& Welfare, Republic of Korea
(03-PJI0-PG I 3-GD0 I-0002). We would like to thank our clinical research nurse Kyung-Hee Lee for her assistance of clinical trial. We thank BioMed Proofreading for English editing services.

\section{References}

I. Esteva FJ, Hortobagyi GN: Locally advanced breast cancer. Hematol Oncol Clin North Am 1999, 13:457-72.

2. Kaufmann M, von Minckwitz G, Smith R, Valero V, Gianni L, Eiermann W, Howell A, Costa SD, Beuzeboc P, Untch M, Blohmer JU, Sinn HP, Sittek R, Souchon R, Tulusan AH, Volm T, Senn HJ: International expert panel on the use of primary (preoperative) systemic treatment of operable breast cancer: review and recommendations. J Clin Oncol 2003, 21:2600-8.

3. Estevez LG, Gradishar WJ: Evidence-based use of neoadjuvant taxane in operable and inoperable breast cancer. Clin Cancer Res 2004, 10:3249-61.

4. Shimizu C, Ando M, Kouno T, Katsumata N, Fujiwara Y: Current Trends and Controversies over Pre-operative Chemotherapy for Women with Operable Breast Cancer. Jpn J Clin Oncol 2007, 37: 1-8.

5. Fisher B, Bryant J, Wolmark N, Mamounas E, Brown A, Fisher ER, Wickerham DL, Begovic M, DeCillis A, Robidoux A, Margolese RG, Cruz AB Jr, Hoehn JL, Lees AW, Dimitrov NV, Bear HD: Effect of preoperative chemotherapy on the outcome of women with operable breast cancer. J Clin Oncol 1998, 16:2672-85.

6. Kuerer HM, Newman LA, Smith TL, Ames FC, Hunt KK, Dhingra K, Theriault RL, Singh G, Binkley SM, Sneige N, Buchholz TA, Ross MI, McNeese MD, Buzdar AU, Hortobagyi GN, Singletary SE: Clinical course of breast cancer patients with complete pathologic primary tumor and axillary lymph node response to doxorubicin-based neoadjuvant chemotherapy. J Clin Oncol 1999, I7:460-9. 
7. Wolmark N, Wang J, Mamounas E, Bryant J, Fisher B: Preoperative chemotherapy in patients with operable breast cancer: nineyear results from National Surgical Adjuvant Breast and Bowel Project B- I 8. J Natl Cancer Inst Monogr 200I, 30:96-I02.

8. Guarneri V, Broglio K, Kau SW, Cristofanilli M, Buzdar AU, Valero V, Buchholz T, Meric F, Middleton L, Hortobagyi GN, Gonzalez-Angulo AM: Prognostic value of pathologic complete response after primary chemotherapy in relation to hormone receptor status and other factors. J Clin Oncol 2006, 24:1037-44.

9. Gonzalez-Angulo AM, McGuire SE, Buchholz TA, Buchholz TA, Tucker SL, Kuerer HM, Rouzier R, Kau SW, Huang EH, Morandi P, Ocana A, Cristofanilli M, Valero V, Buzdar AU, Hortobagyi GN: Factors predictive of distant metastases in patients with breast cancer who have a pathologic complete response after neoadjuvant chemotherapy. J Clin Oncol 2005, 23:7098- 104.

10. Willsher PC, Pinder SE, Gee JM, Ellis IO, Chan SY, Nicholson RI, Blamey RW, Robertson JF: c-erbB2 expression predicts response to preoperative chemotherapy for locally advanced breast cancer. Anticancer Res 1998, 18:3695-98.

II. Chang J, Powles T], Allred DC, Ashley SE, Clark GM, Makris A, Assersohn L, Gregory RK, Osborne CK, Dowsett M: Biologic markers as predictors of clinical outcome from systemic therapy for primary operable breast cancer. I Clin Oncol 1999, 17:3058-63.

12. Mauriac L, MacGrogan G, Avril A, Durand M, Floquet A, Debled M, Dilhuydy JM, Bonichon F: Neoadjuvant chemotherapy for operable breast carcinoma larger than $3 \mathrm{~cm}$ : a unicentre randomized trial with a 124-month median follow-up. Institut Bergonie Bordeaux Groupe Sein (IBBGS). Ann Oncol 1999, 10:47-52.

13. Kandioler-Eckersberger D, Ludwig C, Rudas M, Kappel S, Janschek E, Wenzel C, Schlagbauer-Wadl H, Mittlbock M, Gnant M, Steger G, Jakesz R: TP53 mutation and p53 overexpression for prediction of response to neoadjuvant treatment in breast cancer patients. Clin Cancer Res 2000, 6:50-6.

14. Bonnefoi $H$, Diebold-Berger S, Therasse $P$, Hamilton A, van de Vijver M, MacGrogan G, Shepherd L, Amaral N, Duval C, Drijkoningen R, Larsimont $D$, Piccart M: Locally advanced/inflammatory breast cancers treated with intensive epirubicin-based neoadjuvant chemotherapy: are there molecular markers in the primary tumour that predict for 5-year clinical outcome? Ann Oncol 2003, I4:406-13.

15. Recht A, Edge SB, Solin LJ, Robinson DS, Estabrook A, Fine RE, Fleming GF, Formenti S, Hudis C, Kirshner JJ, Krause DA, Kuske RR, Langer AS, Sledge GW Jr, Whelan TJ, Pfister DG: Postmastectomy radiotherapy: clinical practice guidelines of the American Society of Clinical Oncology. J Clin Oncol 200I, 19:1539-69.

16. Han S, Kim SB, Kang SS, Noh WC, Paik NS, Chang ES, Kim JR, Lim $\mathrm{SH}$, Park HS: A phase II study of neoadjuvant docetaxel plus doxorubicin (KBCS-0I) in stage II, III breast cancer. Breast Cancer Res Treat 2006, 98:57-61.

17. Therasse P, Arbuck SG, Eisenhauer EA, Wanders J, Kaplan RS, Rubinstein L, Verweij J, Van Glabbeke M, van Oosterom AT, Christian MC, Gwyther SG: New guidelines to evaluate the response to treatment in solid tumors. European Organization for Research and Treatment of Cancer, National Cancer Institute of the United States, National Cancer Institute of Canada. J Natl Cancer Inst 2000, 92:205-16.

18. Greene FL, Page DL, Fleming ID, Fritz AG, Balch CM, Haller DG, Morrow M: AJCC cancer staging manual. 6th edition. New York Springer; 2002.

19. Elston CW, Ellis IO: Pathological prognostic factors in breast cancer. I. The value of histological grade in breast cancer: experience from a large study with long-term follow-up. Histopathology 1991, 19:403-4I0.

20. Hsu SM, Raine L, Fanger H: A comparative study of the peroxidase-antiperoxidase method and an avidin-biotin complex method for studying polypeptide hormones with radioimmunoassay antibodies. Am J Clin Pathol 198I, 75:734-8.

21. Lee KH, Im SA, Oh DY, Lee SH, Chie EK, Han W, Kim DW, Kim TY, Park IA, Noh DY, Heo DS, Ha SW, Bang YJ: Prognostic significance of bcl-2 expression in stage III breast cancer patients who had received doxorubicin and cyclophosphamide followed by paclitaxel as adjuvant chemotherapy. BMC Cancer 2007, I 2(7):63.

22. Perez EA, Roche PC, Jenkins RB, Reynolds CA, Halling KC, Ingle JN, Wold LE: HER2 testing in patients with breast cancer: Poor correlation between weak positivity by immunohistochemistry and gene amplification by fluorescence in situ hybridization. Mayo Clin Proc 2002, 77: I 48-54

23. Alizadeh AA, Ross DT, Perou CM, van de Rijn M: Towards a nove classification of human malignancies based on gene expression patterns. J Pathol 200I, 195:4I-52.

24. Chollet P, Amat S, Cure H, de Latour M, Le Bouedec G, Mouret-Reynier MA, Ferriere JP, Achard JL, Dauplat J, Penault-Llorca F: Prognostic significance of a complete pathological response after induction chemotherapy in operable breast cancer. $\mathrm{Br} J \mathrm{Can}$ cer 2002, 86: 104|-6.

25. Bottini A, Dogliotti L, Bersiga A, Brizzi MP, Berruti A: p53 but not bcl-2 immunostaining is predictive of poor clinical complete response to primary chemotherapy in breast cancer patients. Clin Cancer Res 2000, 6:275I-8.

26. Schneeweiss A, Katretchko J, Sinn HP, Unnebrink K, Rudlowski C, Geberth M, Beldermann F, Bastert G, Strittmatter HJ: Only grading has independent impact on breast cancer survival after adjustment for pathological response to preoperative chemotherapy. Anticancer Drugs 2004, 15:127-35.

27. van Slooten HJ, Clahsen PC, van Dierendonck JH, Duval C, Pallud C, Mandard AM, Delobelle-Deroide A, van de Velde CJ, van de Vijver MJ: Expression of $\mathrm{Bcl}-2$ in node-negative breast cancer is associated with various prognostic factors, but does not predict response to one course of perioperative chemotherapy. $\mathrm{Br}$ Cancer 1996, 74:78-85.

28. Yildirim E, Semerci E, Berberoglu U: The analysis of prognostic factors in stage III-B non-inflammatory breast cancer. Eur J Surg Oncol 2000, 26:34-8.

29. Ganem G, Tubiana-Hulin M, Fumoleau P, Combe M, Misset JL, Vannetzel JM, Bachelot T, De Ybarlucea LR, Lotz V, Bendahmane B, Dieras V: Phase II trial combining docetaxel and doxorubicin as neoadjuvant chemotherapy in patients with operable breast cancer. Ann Oncol 2003, 14:1623-28.

30. Bear HD, Anderson S, Brown A, Smith R, Mamounas EP, Fisher B, Margolese R, Theoret H, Soran A, Wickerham DL, Wolmark N: The effect on tumor response of adding sequential preoperative docetaxel to preoperative doxorubicin and cyclophosphamide: preliminary results from National Surgical Adjuvant Breast and Bowel Project Protocol B-27. J Clin Oncol 2003, 21:4165-74

31. Maur M, Guarneri V, Frassoldati A, Conte PF: Primary systemic therapy in operable breast cancer: clinical data and biological fall-out. Ann Oncol 2006, I7:v158-64.

32. Carey LA, Metzger R, Dees EC, Collichio F, Sartor Cl, Ollila DW Klauber-DeMore N, Halle J, Sawyer L, Moore DT, Graham ML: American Joint Committee on Cancer tumor-node-metastasis stage after neoadjuvant chemotherapy and breast cancer outcome. J Natl Cancer Inst 2005, 97: I I 37-42.

33. Chollet $P$, Amat $S$, Belembaogo E, Curé $H$, de Latour M, Dauplat J, Le Bouëdec G, Mouret-Reynier MA, Ferrière JP, Penault-Llorca F: Is Nottingham prognostic index useful after induction chemotherapy in operable breast cancer? $\mathrm{Br} /$ Cancer 2003, 89: ||85-9|.

34. Haffty BG, Yang Q, Reiss M, Kearney T, Higgins SA, Weidhaas J, Harris L, Hait W, Toppmeyer D: Locoregional relapse and distant metastasis in conservatively managed triple negative earlystage breast cancer. J Clin Oncol 2006, 24:5652-7.

35. Rakha EA, El-Sayed ME, Green AR, Lee AH, Robertson JF, Ellis IO: Prognostic markers in triple-negative breast cancer. Cancer 2007, 109:25-32

36. Carey LA, Dees EC, Sawyer L, Gatti L, Moore DT, Collichio F, Ollila $\mathrm{DW}$, Sartor $\mathrm{Cl}$, Graham ML, Perou CM: The triple negative paradox: primary tumor chemosensitivity of breast cancer subtypes. Clin Cancer Res 2007, 13:2329-34.

37. Rouzier R, Perou CM, Symmans WF, Ibrahim N, Cristofanilli M, Anderson K, Hess KR, Stec J. Ayers M, Wagner P, Morandi P, Fan C, Rabiul I, Ross JS, Hortobagyi GN, Pusztai L: Breast cancer molecular subtypes respond differently to preoperative chemotherapy. Clin Cancer Res 2005, I I:5678-85.

38. Sorlie T, Perou CM, Tibshirani R, Aas T, Geisler S, Johnsen H, Hastie $T$, Eisen MB, van de Rijn M, Jeffrey SS, Thorsen T, Quist H, Matese JC, Brown PO, Botstein D, Eystein Lonning P, Borresen-Dale AL: Gene expression patterns of breast carcinomas distinguish tumor subclasses with clinical implications. Proc Natl Acad Sci USA 200I, 98: 10869-74. 
39. Brenton JD, Carey LA, Ahmed AA, Caldas C: Molecular classification and molecular forecasting of breast cancer: ready for clinical application? J Clin Oncol 2005, 23:7350-60.

\section{Pre-publication history}

The pre-publication history for this paper can be accessed here:

http://www.biomedcentral.com/1471-2407/7/203/pre

pub

Publish with Bio Med Central and every scientist can read your work free of charge

"BioMed Central will be the most significant development for disseminating the results of biomedical research in our lifetime. " Sir Paul Nurse, Cancer Research UK

Your research papers will be:

- available free of charge to the entire biomedical community

- peer reviewed and published immediately upon acceptance

- cited in PubMed and archived on PubMed Central

- yours - you keep the copyright

Submit your manuscript here:

http://www.biomedcentral.com/info/publishing_adv.asp
BioMedcentral 